\title{
The Burial Ground: A Bridge Between Language And Culture
}

\author{
Allison Burkette* \\ University of Mississippi
}

This paper explores the cultural and historical forces that created variation in terms for "cemetery", including links between language and material culture, using cemetery terms found within two Linguistic Atlas data sets to demonstrate how colonial influence, cultural changes, and physical locations contribute to linguistic variation. Speakers' lexical choices in the 1930s still show the effects of the religious and social climates of the seventeenth and eighteenth centuries. Northern and southern colonial trends were still influencing regional language use several hundred years later. Furthermore, for the LANE data we find that the physical location of historic cemeteries has an effect on speakers' use of specific lexical items.

When suddenly you know that the geographical history of America has something to do with everything. -Gertrude Stein

\section{Introduction}

Francaviglia (1971) makes a case for the study necrogeography, stating that "the cemetery in the United States is a microcosm of the real world" (501); we can see the prejudices, power structures, and tastes of that real world mirrored by the layout of the cemetery. The values and beliefs of the living are thus reflected by the cemetery, which stands as a "visual and spatial expression of death" (509). More recent work in anthropology reiterates the importance of the cemetery as a locus for community expression. Francis (2003) explains that cemeteries are a "collective representation" of a community's beliefs about the relationship between the living and the dead (223). The materiality of the cemetery locates the dead within "living time and ordered space" (223). Burying spaces provide a way to keep the dead close by, both literally and figuratively. Miller and Rivera (2006) discuss the cemetery as a link between past and present, as the physical place is then the "point of connection between this world and the next" (335). Not only do burying places provide a bridge between the living and the dead, the past and the present, the known and unknown, they also provide an excellent illustration of the bridge between language and culture.

This paper will explore the cultural and historical forces that created variation in terms for 'cemetery', including links between language and material culture, using cemetery terms found within two Linguistic Atlas

*Address for correspondence: Allison Burkette, C-115 Bondurant Hall, Department of Modern Languages, University, MS 38677 (662) 915-1458, Email: burkette@olemiss.edu data sets to demonstrate how cultural changes and physical locations influence and contribute to linguistic variation.

\section{Linguistic Atlas Project}

The Linguistic Atlas Project (LAP) offers us a sweeping view of language variation. The project as a whole is broken into several smaller, regional projects. The first of these sub-projects is the Linguistic Atlas of New England (LANE), with 416 interviews in seven states, conducted between 1931 and 1933. LANE was followed by the Linguistic Atlas of the Middle and South Atlantic States (LAMSAS), fieldwork for which was conducted in the 1930s and 40s. LAMSAS consists of data from 1,162 speakers from ten different states.

For all of the Linguistic Atlas projects, the targets of inquiry were mostly lexical, terms for items and creatures and happenings around the home and farm. Topics covered include weather, food, furniture, animals, farm equipment, illness, and social institutions. In addition, the worksheets contained a number of grammatical targets, such as the principal parts of verbs, pronouns (e.g. you and I, himself, themselves), agreement (e.g. people thinks and they say), the verbs be, have and do (found in target phrases such as I'm going, you were talking, he does), as well as modals, adverbs, prepositions, and conjunctions. A number of items within the set of grammar targets have more "discourse-like" responses, such as, no thank you and if you're a mind to. The Atlas worksheets also contained questions designed to elicit phonological targets, such as the pronunciation of selected cities and states, the pronunciation of specific words (such as chimney), and the pronunciation of items designed to outline a speaker's articulation of English vowels. Several items do double-duty in that they hit a combination of lexical and phonological targets or grammar and discourse targets. 
Atlas targets were acquired primarily through longer length questions that call for one-word answers. These questions were either descriptive phrases that asked the interviewee to name the item being described (these were often framed by the phrase, "what would you call [description]") or they were fill-in-the-blank questions that asked the speaker to supply the target as the missing word. The responses to each question are considered variants of a single target. ${ }^{1}$ No matter what the target, the Atlas interviewees' responses represent wide and various collections of linguistic material.

Linguistic Atlas data is valuable in terms of the cultural information stored within its databases. The Atlas survey covered many everyday items and the variation found within the terms for those items is very much tied to the cultural and historical forces that inform different regions. Among the questions asked of Linguistic Atlas informants were the following, intended to elicit variants of 'graveyard' (found as LAP item number 78.8).

1) Lowman: Place where people are buried.

2) McDavid: They laid him away in the __. If it's very small and out in the country, you'd call it a If it's very small and on the farm, you'd call it a Other names? As around the church?

The present investigation examines the responses to these questions from LANE and LAMSAS speakers, turning then to history and to material culture for explanations of the geographic distributions we find for specific cemetery terms. What we find is that Gertrude Stein was correct in suggesting that there are moments "when suddenly you know that the geographical history of America has something to do with everything".

\subsection{The LANE data}

The LANE responses to the 'cemetery' question are comprised of 26 response types that combine for a total of 905 tokens. LANE responses and their respective frequencies can be found in Table 1; the distribution of each of these terms within the LANE territory can be viewed as part of the mapping function of the Google fusion table found here (click here for Fusion Table 1). The fusion table itself contains columns with each LAP speaker's Informant number, age, sex, and response to the 'cemetery' question, along with their community's geo-coordinates. By selecting the Map of Location tab, one can view the informants' locations and, by using the filter function, see a breakdown of the 'cemetery' responses and select specific responses to map. By mousing over an individual red dot, one can view the particulars for each occurrence of the selected response (i.e. the informant number, age, etc. associated with the speaker that the dot represents).
Table 1. LANE responses to the 'cemetery' question.

\begin{tabular}{lr}
\hline cemetery & 386 \\
graveyard & 251 \\
burying ground(s) & 211 \\
churchyard & 25 \\
burial ground & 17 \\
boneyard & 6 \\
God's acre & 6 \\
burying place & 4 \\
burial lot & 2 \\
old term was burying ground & 2 \\
private burying ground & 2 \\
old burying ground & 2 \\
the yard & 2 \\
burial cemetery & 1 \\
burying hill & 2 \\
burying & 1 \\
burying field & 1 \\
burying spot & 1 \\
burying yard & 1 \\
hill & 1 \\
hospital & 1 \\
kirkyard & 1 \\
potter's field & 1 \\
private burial lot & 1 \\
the white city & 1 \\
used to be burying ground & 1 \\
& 1 \\
\end{tabular}

Together, the three most common responses, cemetery, graveyard and burying ground, account for $94 \%$ of the data, with cemetery accounting for almost half. The next most frequent responses, churchyard and burial ground, demonstrate a dramatic drop-off in frequency, together accounting for just over $4 \%$ of the data. Though they vary in their particulars, most Linguistic Atlas Project databases evidence this same frequency profile: a handful of frequent core terms and a great number of peripheral terms given only once or twice.

\subsection{The LAMSAS data}

From the LAMSAS interviews, we find that the "cemetery" question elicited 2,342 responses that represent 59 different response types. The response types and their frequencies can be found in Table 2, and again the distribution of each response can be viewed using a Google fusion table (click here for Fusion Table 2). For the LAMSAS data, the fusion table contains columns for LAP Informant number, locality (whether urban or rural), sex, age, ethnicity, and education level, along with the corresponding community geo-coordinates.

Looking at the LAMSAS responses and their distribution, we see that the two core terms, cemetery and graveyard, together make up $82 \%$ of the total 
Table 2. LAMSAS responses to the 'cemetery' question.

\begin{tabular}{|c|c|}
\hline cemetery & 999 \\
\hline graveyard & 907 \\
\hline burying ground & 214 \\
\hline churchyard & 51 \\
\hline potter's field & 26 \\
\hline burial ground & 24 \\
\hline family burying ground & 13 \\
\hline family graveyard & 13 \\
\hline God's acre & 7 \\
\hline boneyard & 6 \\
\hline grave & 5 \\
\hline burying plot & 4 \\
\hline family plot & 4 \\
\hline private graveyard & 4 \\
\hline burying place & 3 \\
\hline church cemetery & 3 \\
\hline pauper's field & 3 \\
\hline plot & 3 \\
\hline potter field & 3 \\
\hline begraafplaats & 2 \\
\hline burial lot & 2 \\
\hline burial place & 2 \\
\hline city of the dead & 2 \\
\hline family lot & 2 \\
\hline lot & 2 \\
\hline mausoleum & 2 \\
\hline memorial garden & 2 \\
\hline private burying ground & 2 \\
\hline tomb & 2 \\
\hline at the church & 1 \\
\hline burial yard & 1 \\
\hline burying & 1 \\
\hline burying ground plot & 1 \\
\hline burying lots & 1 \\
\hline burying yard & 1 \\
\hline cemetery yard & 1 \\
\hline church lot & 1 \\
\hline crypt & 1 \\
\hline enclosure & 1 \\
\hline family burial ground & 1 \\
\hline family burial lot & 1 \\
\hline family cemetery & 1 \\
\hline family enclosure & 1 \\
\hline final resting place & 1 \\
\hline God's acres & 1 \\
\hline God's half-acre & 1 \\
\hline head stick & 1 \\
\hline hollowed ground & 1 \\
\hline home cemetery & 1 \\
\hline home graveyard & 1 \\
\hline interment place & 1 \\
\hline last resting place & 1 \\
\hline national cemetery & 1 \\
\hline negro graveyard & 1 \\
\hline pauper's graveyard & 1 \\
\hline pauper's lot & 1 \\
\hline Spanish burying ground & 1 \\
\hline square & 1 \\
\hline tombstone & 1 \\
\hline
\end{tabular}

"cemetery" responses. The LAMSAS data evidence the same frequency profile seen in the LANE data above, though the order of responses within that profile differs. The LANE data set contains three core terms, while the LAMSAS set contains two terms whose frequencies account for the majority of responses from this region. In addition, the sharp drop-off between core and peripheral in the LAMSAS data set occurs at the term burying ground, which, despite its popularity in the LANE territories, accounts for only $9 \%$ of the mid- and south Atlantic states' data.

All told, these databases contain over 65 variants of 'cemetery', twelve of which are found in both regional data sets. Many of the variants are the result of the linguistic processes of modification and compounding. Given the top three terms for both of the surveys (cemetery, graveyard, burying ground), we find that many of the peripheral responses are the result of adding a modifier or the result of compounding. There are, for example, five response types that contain cemetery from LAMSAS (church cemetery, cemetery yard, home cemetery, national cemetery, and family cemetery) and one additional response from LANE (burial cemetery). The LAMSAS survey responses also include five terms that contain graveyard (family graveyard, private graveyard, home graveyard, negro graveyard, and pauper's graveyard). Within the LAMSAS and LANE data we also find burying (or burial) being used to build compounds with ground, place, lot, plot, field, yard, and hill which creates a whole range of terms that can then also be modified, ergo responses such as family burial ground and private burying ground. Many of these modifiers reflect a contrast between private and public grounds, a distinction that is not unrelated to social class and/or ethnic designations (e.g. potter's field, a term used to designate a pauper's graveyard).

These terms also evidence a distinction between the terminology preferred by the colonial Puritans (terms containing burial or burying), terms that highlight family-based burial practices (e.g. family burying ground, family plot, family cemetery, etc.), and those that highlight church-based practices (churchyard, church cemetery, etc.), and it is here that we find the most striking regional differences. Described by the Dictionary of American Regional English (DARE) (Cassidy \& Hall, $1985)$ as "archaic", the term burying ground makes up $23 \%$ of the LANE responses, but only $9 \%$ of LAMSAS responses. That burying ground, a term whose distribution DARE describes as "scattered", is considered old-fashioned, is perhaps reflective of its shared history with burial ground. Though not an overwhelming percentage of either data set's responses, burial ground is the fourth most frequent response for LANE, but the sixth most frequent in LAMSAS. This distribution is reaffirmed by $D A R E$, which also labels this term as 
primarily Northern, which makes sense given its colonial roots. While the distribution of churchyard and church-compounded terms is scattered throughout both regional surveys, terms that contain family as a modifier are found only in LAMSAS. These distributions are the result of fundamental differences between burial practices in colonial New England and those in the early American South.

At this point, it is useful to take a quick look at American colonial and post-colonial burial practices in order to understand where (and why) the basic cemetery terms took root and the subsequent deployment of those terms across the LANE and LAMSAS regions.

\section{A Brief History of American Burial Practices}

\subsection{Northeastern burial practices (1600-1820)}

The earliest organized cemeteries in colonized America were Puritan burying grounds (or burial grounds, burying places, burial places) which were open, public spaces in the center of town, spaces that were used for animal grazing as well as for the interment of human remains. In Boston, we find the oldest of the Northeastern burying grounds, several of which were established in the early 1630s. Puritan doctrine held that every person deserved death and damnation and that belief in God provided hope, but did not provide security. Children were not exempt. In a eulogy delivered in 1708, "Corderius Americanus," Cotton Mather entreated his young listeners to be ever mindful that death was around every corner, "Go into the Burying-Place, CHILDREN; you will there see Graves as short as your selves." With both time of death and postdeath destination predetermined, Puritan funerals were simple and short; not much ceremony is necessary if nothing can be done to alter the deceased's eternal fate.

Considering it to be a Papist practice, Puritans eschewed the burial of their dead near their churches (which they referred to as "meetinghouses"). Puritan doctrine didn't demand much in the way of grave marking. These early American graves were most likely unmarked, or, if they were marked, it was with simple wooden stakes. ${ }^{2}$ Some Puritan graveyards had only a single placard to indicate that the area was a burying ground. Carved markers became more common after $1650 .^{3}$ The earliest and most common motif discernable on northern grave markers is a "death's head" carved in the gravestone's lunette. This image of a skull with wings serves as a reminder of the immediacy of death and reiterates the lessons of Puritan sermons that emphasized mortality and frequently offered "graphic depictions of ones' mortal remains" (Dethlefsen \& Deetz, 1966:56).

In the late 1600 s, a system of death notification was established. An inviter would take gloves, scarves, and possibly food and drink to family and friends of the deceased to invite them to a funeral (for the Pennsylvania Deutsch, a warner would inform friends and family, bringing doed koeks as tokens of remembrance). By 1691, inviters were viewed as public servants (Coffin, 1976). ${ }^{4}$ By the early 1700s, Enlightenment ideas about death had reached America, including the view of death as a natural part of life. ${ }^{5}$ Funerals became larger events as they shifted from being markers of death to celebrations of life.

Soon after, America underwent its first Great Awakening, the term used for the period between 1730 and 1750 that marked a heightened intensity of religious belief. This revival of religious enthusiasm was led in part by Jonathan Edwards, who was influenced both by the Enlightenment and his own Puritan background. Edwards' famous 1741 sermon, "Sinners in the Hands of an Angry God," while still graphically emphasizing the threat of Hell, turned toward the topic of atonement (and does not once mention "graves" or "burials"). At this time, we see a shift in Puritan teachings, a move away from the certainty of death and toward the joys of life. The shift occurred not only in sermons, but on gravestone lunettes as well. The death's head motif was gradually replaced by the beatific cherub, a human face with wings, seen as a representation of eternal hope. Once death was perceived as less commonplace, the "harsh reality" of its occurrence was physically "muted and beautified" (Jackson, 1977:230). The use of the human figures on gravestones eventually faded; between 1760 and 1820, the cherub motif receded as the willow and urn motif took its place. ${ }^{6}$ The willow and urn motif highlighted the sentimentality of death, with the willow as a symbol for mourning and the urn as a symbol of the soul. ${ }^{7}$

\subsection{Southern Burial Practices (1600-1820)}

Early Southern burials occurred in two types of locations: the churchyard and the family graveyard. While Puritan distaste for what was considered a papist practice prevented churchyard burials in the northern colonies, Southern colonial burials kept to the British tradition of burial in churchyards. Recent archaeology at Jamestown, led by Douglas Owsley, has uncovered the earliest known colonial burials (1607-1608), located beside the first churches built within the Jamestown fort (Epstein, 2015). Even small churches had a space for the interment of congregation members.

After the earliest Virginia plantations were disrupted by the Powhatan uprising of 1622, colonists moved outward, building their own, family-based tobacco plantations along the James River. This had the effect of drawing burials away from churches and into family burial grounds as church locations became peripatetic, 
working to serve populations that moved around and shifted in size frequently. Because of this practice, home burials became the norm in the southern colonies by the 1630s-40s (Carl Lounsbury, pers. comm. July 21, 2015), and were usually located on a hilltop. ${ }^{8}$

The earliest southern graves, like their northern counterparts, had no permanent markers; dirt mounds were used to mark where the deceased lay. These mounds were scraped and kept clear of grass, a practice found in the British Isles, possibly one that reflects an older Germanic tradition (Jeane, 1992:113). A clean cemetery was considered a sign of proper devotion to the deceased; graves were maintained and re-scraped by families, townspeople or church congregations on community workdays that could also serve as a social gathering. In addition to scraped mounds and graveyard workdays, creative grave decorations (such as personal items or seashells) and the use of wooden rails or stones to demarcate grave areas were distinctive characteristics of upland south burials (Jeane, 1992:108).

In truth, however, the earliest burial practices of colonialized America were varied and the earliest colonial burials differed quite a bit from what would later become standard practice. Weglian (2006) uses an archaeological sample from the Chesapeake Bay area to evaluate the uniformity of early American burial practices, and finds that the earliest graves (pre-1650) do not exhibit the same characteristics as the American norm that arises in the latter half of the $17^{\text {th }}$ century. Differences in body orientation (early graves did not necessarily reflect an east-to-west orientation), the interment of a body in a flexed position (unheard of after 1650), the absence of mortuary clothing or shrouds (ubiquitous in post-1650 burials), and group burials (a practice found only in the earliest of grave sites) mark colonial graves as reflective of different resources, values, and attitudes towards the disposal of the dead. By the end of the $17^{\text {th }}$ century, however, American burial practices lost that flexibility and followed more closely the British standards and fashions (Weglian, 2006:205-6). Weglian also notes that, early on, white servants and enslaved blacks were not segregated in burial; early southern burial space was initially based on "occupation and bondage ... rather than along racial lines" (Weglian, 2006: 207, also c.f. Jamieson, 1995). ${ }^{9}$

\subsection{American Burial Practices (1820 on)}

Prior to the Civil War, and in part because of the Great Awakening, America experienced a lightening of sentiment about death, reflected most obviously in the shift in terms for burying places, from the transparent burial place, graveyard, or boneyard to the more euphemistic and opaque cemetery (taken from the Greek

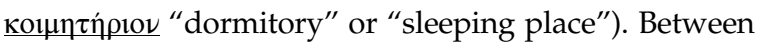
1830 and 1855, the rural cemetery (or garden cemetery) arose, a development that coincided (and not coincidentally) with the growth of landscape architecture as a profession. The traditional churchyard cemetery stood in stark, organized contrast to the more curvilinear rural cemetery, which looked more like a park than a graveyard.

Boston's Mount Auburn Cemetery is a perfect example of the rural cemetery. Conceptualized by Dr. Jacob Bigelow (a botanist and physician) as early as 1825, Mount Auburn was intended to be both a botanical garden and a "garden of graves" (Farrell, 1980:101). ${ }^{10}$ Given the growth of urban areas and the mobility of people living there, it made sense to move burial grounds outside of the city. Visitors could travel a short way in order to "commune with God, with Nature, and with deceased family and friends" all at one time (Farrell, 1980:105). Graves were no longer mounded or marked-off, and upright markers were replaced with ground-level ones, both of which de-emphasize the visible reminders of death and re-emphasize the idea of death as an equalizer. The use of personal items as grave decoration were restricted to those associated with children only.

During the mid to late 1800 s, cemeteries were subject to the further removal of the appearance of death, which contributed to the development of the lawn cemetery or park cemetery. Around the same time that Central Park in NYC was being designed (1857), Adolph Strauch was designing Cincinnati's Spring Grove Cemetery (1855), with the aim of getting rid of the "hideous ironmongery" of lot enclosures (Farrell, 1980:113). The Association of American Cemetery Superintendents (AACS) was formed in 1887 and, as an association, pushed for parklike cemeteries. They believed in upholding the "cemetery plan" over catering to the whims of individual preferences. ${ }^{11}$ These modern cemeteries were founded on business principles; if the rural cemetery design was aimed at beauty, the lawn-park cemetery was "a marriage of aesthetic ideals to the gospel of efficiency" (Farrell, 1980:120). These lawn-park cemeteries included lakes, paths, and winding roads (like the rural cemetery) but with some modifications, such as the prohibition of lot or grave enclosures, the lack of grave mounding, and a strong preference for fewer and smaller grave markers. Some AACS members wanted to eliminate markers altogether; A.H. Sargent argued at the second annual AACS meeting that, "grief is not measured by the number and height of stones. The deepest grief is the quiet kind" (as quoted in Farrell, 1980:123). ${ }^{12}$ Though the AACS officially recommended that grave markers resemble boulders with a little plaque that had a name and two dates (or, better yet, just a family name), the public continued to demand formal markers and benches. However, no matter how 
the resting place of the deceased was marked, the rural and lawn-park cemeteries worked to smooth over the reality of death. By the early 1900s, to paraphrase Gertrude Slaughter, ${ }^{13}$ hell had lost its terrors and heaven had lost its charms (1916:917).

The popularity of rural cemeteries and of lawn-park cemeteries moved death to the outskirts of daily life, which some historians have noted as analogous to the development of the modern suburb, a phenomenon of the same time period. Early suburbs and rural cemeteries "feature[d] natural scenery and winding roads that contrasted with the artificial architecture and grid-patterned streets of the cities" (Farrell, 1980:110). A single design to take care of the living and the dead.

Death returned, however, and in the 1920s there was a renewal of cemeteries that look like graveyards. Populated by gravestones, monuments, benches, etc., there was a "recall of mystery" following the onset of World War I (Farrell, 1980:143). Death appeared, for a while, to be a fashionable curiosity as rapid urbanization after WWI spread the "Victorian cult of death" that traveled from England to the U.S. in the early 1900s (Jackson, 1977). During the Victorian era in England, death had become a prominent literary theme, as novels hinged on deathbed scenes and protagonists were motivated to act by the threat of child death (Reed, 1975:160).${ }^{14}$ At the same time, concern for the care and protection of the body grew as "awareness" of the afterlife became entrenched in popular culture (e.g. the vogue of spiritualism, characterized by Ouija boards and séances). For believers, dying was viewed as merely a status change (Jackson, 1977:232). The American version of the cult of death ended as the impending doom of World War II descended.

The memorial park (or memorial garden) developed in the 1920s, as a hybrid of the rural cemetery and the lawn-park cemetery. Memorial park first appeared in writing in 1927, among the "Miscellany" of a 1934 volume of American Speech. ${ }^{15}$ In the post-war era, the memorial park becomes the model for cemeteries in both urban and rural areas. Located out of sight from highly populated areas, the memorial park had plastic flowers, standardized grave markers, hired caretakers, and little vegetation. ${ }^{16}$ The lack of maintenance necessary for cemetery upkeep gave rise to another name for this type of burying ground-perpetual care cemetery-a name that emphasizes the fact that customers don't have to look after the dead themselves.

\section{Discussion: Historical and Material Connections}

Given this historical context, we can begin to make some connections between colonial groups and their burial practices, cultural shifts in beliefs about death, and the 'cemetery' terms we find within the LAP data.

The first distinction in American 'cemetery' terms stems from the contrast between the Puritan use of burying ground (or burial ground) and the non-Puritan use of churchyard. In this particular case, lexical variation reflects the founding influence of two distinct theological approaches to the interment of the dead. The colonial Puritan influence in New England perseveres, resulting in higher percentages of Puritan-based variants within the LANE database. Though the use of burying ground is scattered across the LANE territory (and is not uncommon within LAMSAS, even in southern states), the use of burial ground by the LANE speakers appears particular to areas of early colonial settlement, places heavily influenced by Puritan beliefs and practices where "burial ground" and "burying ground" are likely to be found within historic cemetery place names. Thus, the use of burial ground by LANE speakers in the early 1930s is anchored in the material world, within the cemetery place names in the New England area.

Using the U.S. Park Service's National Register of Historic Places, cemeteries in New England were geocoded and entered into a Google fusion table, resulting in a list of 142 cemeteries founded (or first used for interment) between 1620 and 1898. (click here for Fusion Table 3). The table contains columns for cemetery name, year founded, location (city, state), and geo-coordinates.

A quick glance at the list of these New England cemeteries ordered by date reveals a gradual shift in names for these locations from burying (burial) ground to cemetery. Of the 11 locations founded before 1650, we see that eight contain burying ground or burial ground in their names. Moving forward in time, we find that, of the 34 locations founded between 1850 and 1900, only one is referred to as a burying ground. A handful of the LANE responses themselves support the assessment that these are older terms (as in "old term was burying ground", "old burying ground", and "used to be burying ground").

If we map together the historic cemeteries and the LANE responses to the 'cemetery' question, we find the distribution below. This screenshot (Map 1) plots the locations of cemeteries whose registered name includes "burying ground" or "burial ground" (blue dots), along with occurrences of burial ground (red dots) within the LANE data. The cluster of blue dots reflects the fact that Boston was an early cultural center that grew out of the Massachusetts Bay Colony, while the additional pairs of blue dots along the New England coast are located near other sites of early colonization. The majority of LANE burial ground responses to the 'cemetery' question, were given by speakers whose 


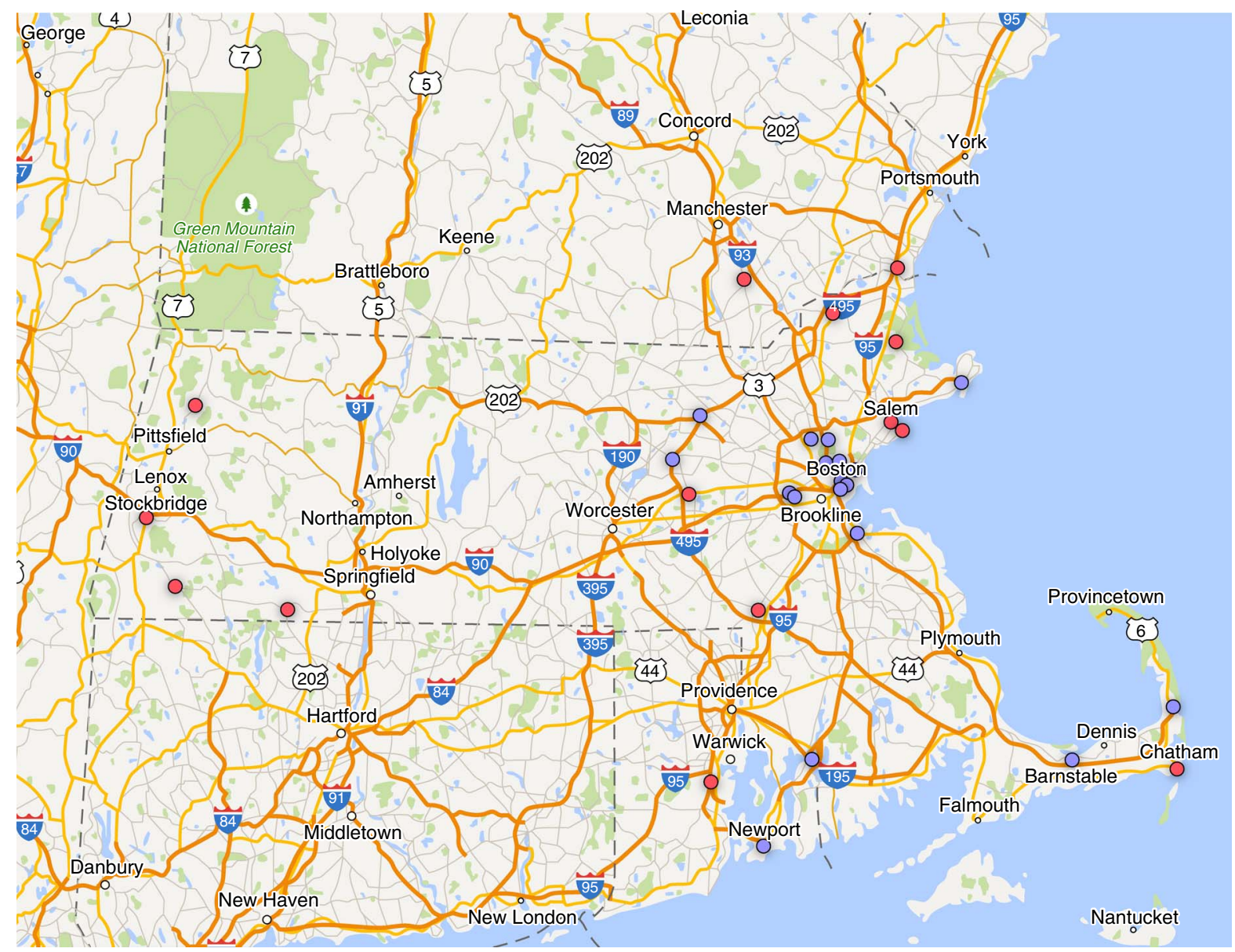

Map 1. LANE burial ground responses mapped with cemetery placenames.

community was within 50 kilometers of one of these early cemeteries. (click here for Fusion Table 4)

The presence, then, of burial ground and the predominance of burying ground in the LANE territory (along with the presence of 12 additional burial/burying terms) is tied to and reinforced by the proper names of actual cemeteries in New England; burial ground particularly is a response given by speakers who lived near early New England settlements. The occurrence of burial ground radiates out from the New England colonial hearth, an area that includes Plymouth (settled in 1620), Gloucester (1623), Boston (1630), Woburn (1640), Newton (1630), and Quincy (1625). Even though all of these early settlements were not Puritan, and even though the pattern is by no means perfect, we can clearly see that even 300 years later, the influence of Puritan beliefs about death and burial on (relatively) contemporary speakers' choice of burial ground for a cemetery.

While burial/burying terms account for almost $27 \%$ of the LANE responses, these terms account for only $11 \%$ of the LAMSAS responses to the 'cemetery' question. The term churchyard, on the other hand, accounts for less than $3 \%$ of each survey database. The distribution of churchyard over the LANE survey territory is scattered, but its distribution within the LAMSAS territory, evidences the influence of British burial practices that were transplanted to the southern colonies.

The LAMSAS distribution of churchyard (see Map 2) is concentrated in South Carolina and Georgia (in fact, 29 out of 52 of the occurrences of churchyard are from South Carolina), states that were home to two early Southern colonial centers, Charleston and Savannah. In addition, this same area contains the majority of responses that include the word family as well (and again, no instances of family-based terms are found within the LANE data). Map 3 is a map of the locations where LAMSAS speakers responded to the 'cemetery' question with one of the family-based terms.

The southern distributions found in Maps 2 and 3 mesh with descriptions of southern burial practices, which mediated death through church and family rather than through secular community practices. 


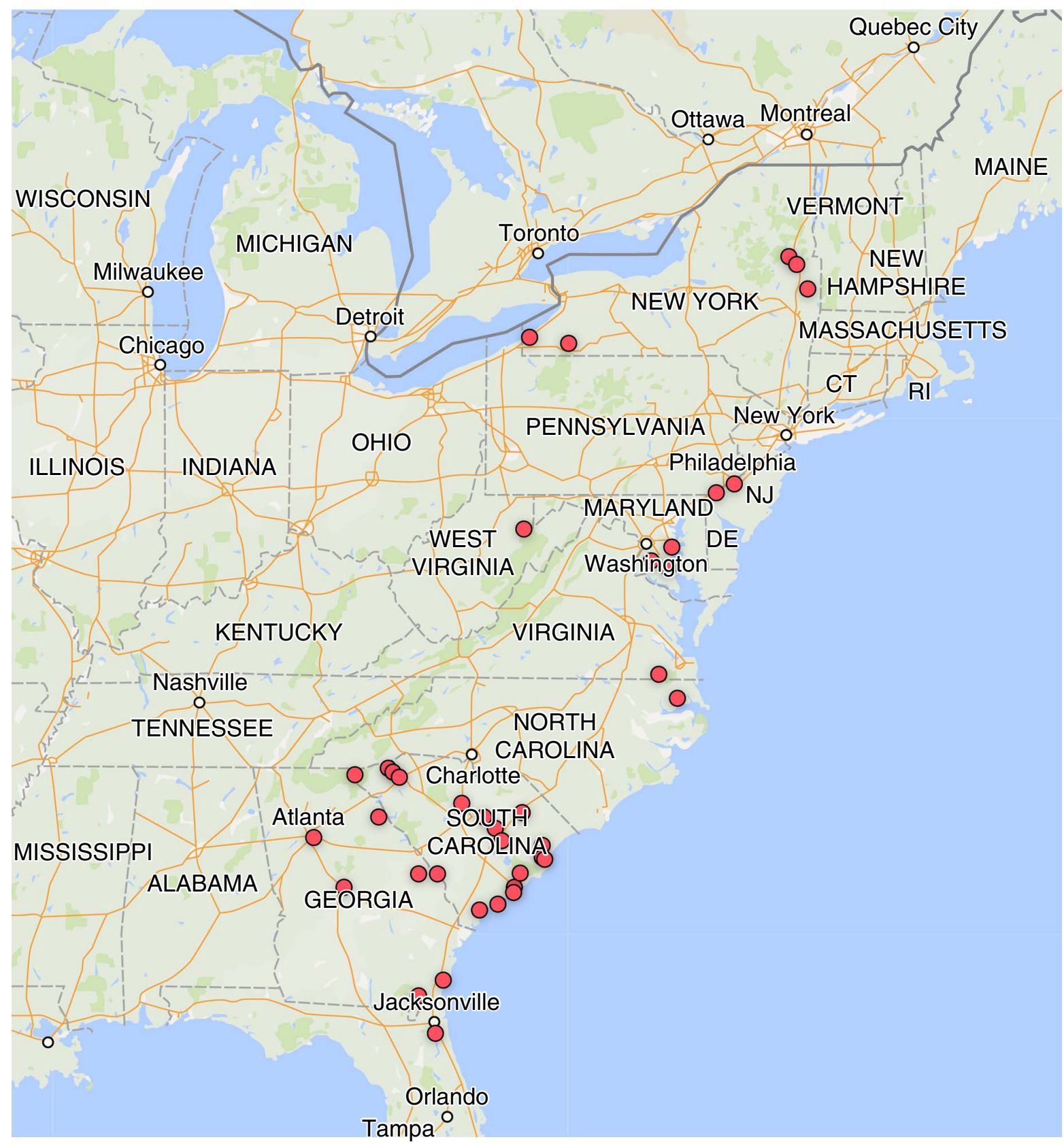

Map. 2. LAMSAS churchyard responses.

In rural areas of the South, the earliest graves are often in small family graveyards, while the more recent burials (beginning two to three generations ago) have taken place beside churches that set aside space for family grave groupings. Though it is possible to do so with the LANE data, the link between the names associated with physical locations and LAMSAS responses is harder to establish, as most family graveyards are not 'official' and are thus not named on the National Registry of Historic Places. Most of the cemetery entries for southern states on the Registry are named as "cemetery" or, less frequently, "graveyard", and are often paired with the name of a church (e.g. the Old Stone Church and Cemetery in S.C. or the Old White Church Cemetery in N.C.).

Note that the LANE database contains no mention of the memorial park or memorial garden-style cemetery. The LAMSAS database contains only two occurrences of memorial garden, both of which were given by speakers in Georgia. The rise of the park cemetery in the late 1800 s appears not to have been able to unseat the colonially established preferences 


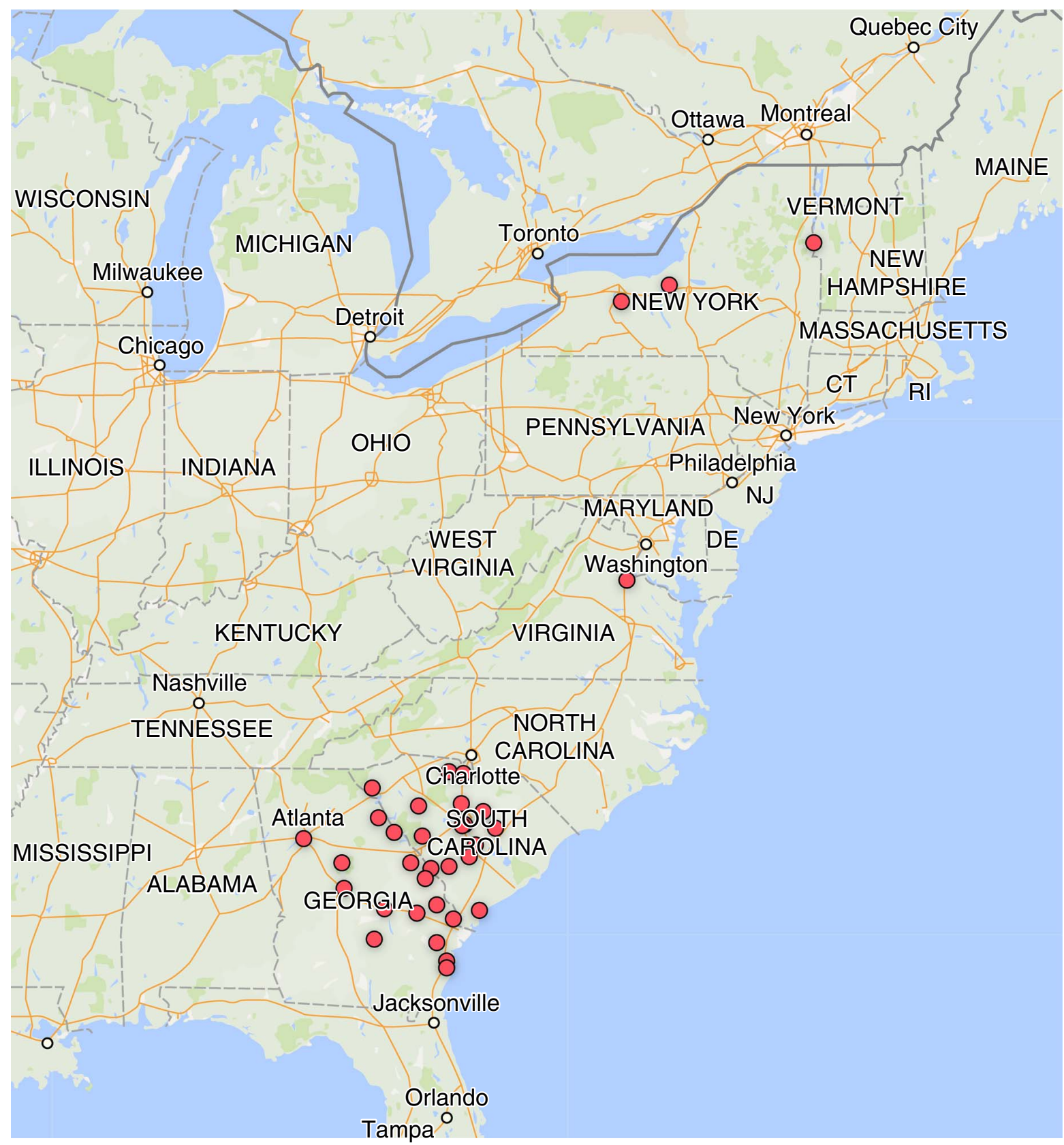

Map. 3. LAMSAS family-based responses.

of east coast speakers. Moving ahead further in time (and slightly further west), we can look at the responses to the 'cemetery' question from another regional survey, the Linguistic Atlas of the Gulf States (LAGS), whose interviews were conducted in the late 1970s. Out of the 1,562 'cemetery' responses found in LAGS, there are four occurrences of memorial garden, four occurrences of memorial park, along with two occurrences apiece of garden and park, which may also refer to the same kind of cemetery. Perhaps as we move away from the east coast we find speakers less firmly entrenched in older terms, such as burying ground, burial ground, and churchyard, which together account for less than $4 \%$ of the LAGS responses.

Like all Linguistic Atlas databases, the responses to the 'cemetery' question result in a frequency profile that represents a nonlinear distribution: a few response types account for the majority of response tokens, while a large number of types occur only one or two times (cf. Kretzschmar, 2009; Burkette, 2013, 2015). Although the thrust of the present discussion has centered around the more frequently-given responses to the 'cemetery' question found within the LANE and LAMSAS data, the less-frequent variants-even the 
"onesies" and "twosies"-are not without cultural and historical charm. For example, the LAMSAS response begraafplaats (the Dutch term for 'burying place') was given by a speaker from New York, which makes sense given the early Dutch settlement of that area. The term burying place itself is found in the LANE data with a pronounced coastal distribution and as scattered LAMSAS responses in North and South Carolina. God's Acre, found in both LANE and LAMSAS, is a term associated with the Moravian Church, members of which immigrated to the United States from Herrnhut, Germany, in the mid-1700s. ${ }^{17}$ Other infrequent variants may reflect contact with (or knowledge of) regional variants from other places. City of the dead, for instance, is a term used for cemeteries that, because they lie below sea level, are populated by rows of mausoleums so that the dead can (wisely) be laid to rest above-ground. Popular in New Orleans, this term occurs only twice within the LAMSAS data, once in South Carolina and once in Georgia. Some of the less frequent terms are ones that DARE would label as "jocular" designations, such as boneyard (found in both LANE and LAMSAS) as well as bone orchard and skull orchard (both of which are found as infrequent responses in LAGS). Two tangential lessons can be taken away from the less-frequent responses. The first is that, while there is not necessarily a historical explanation or connection for every lexical LAP response, there are historical and cultural stories to be told about many of them. The second lesson is that, collectively, speakers hang on to words for a long time, a sentiment that conjures William Faulkner's famous statement that, "The past is never dead. It's not even past."

\section{Conclusion}

The relationship between language variation and social variables (e.g. sex, ethnicity, social class, etc.) is welltraveled territory in sociolinguistics, and the addition of detailed descriptions of internal constraints on the appearance of specific variables has deepened our understanding of the "why" and "how" of linguistic choice. What the present paper suggests is an additional means of addressing that variation and those choices: by examining the relationship between language and cultural history. This study finds that speakers' lexical choices in the 1930s still show the effects of the religious and social climates of the seventeenth and eighteenth centuries. Northern and southern colonial trends were still influencing regional language use several hundred years later. For the LANE data, specifically, mapping lexical items and material culture items together suggests that the physical location of historic cemeteries had an effect on LANE speakers' use of specific lexical items. Speakers who lived in close proximity to old burying or burial grounds (i.e. cemeteries named as such) still produced the term burial ground in answer to a direct question about cemeteries. In this case, language use appears to be anchored by a physical presence.

Further research needs to be done in regards to the relationship between language and material objects; the present analysis could be extended to furniture, farming terms, or names for household items, once a set of best practices is established for documenting the origins of physical objects for the purpose of geocoding. That being said, the present study also needs to be extended to more recent Linguistic Atlas data, not only to LAGS, but also to data collected in more recent LAP surveys (e.g. the Linguistic Atlas of the Western States) in order to see if the trends described here continue as expected both through time and with movement westward. With the addition of more recent data, a time depth element can be added to the mapping, so that we can visualize both how and where naming trends change over time.

\section{Acknowledgments}

I would like to thank Carl Lounsbury, architectural historian for Colonial Williamsburg, for his encouragement and for the inside information on the Jamestown burials. Many thanks also go to Maureen Meyers of the University of Mississippi for her archaeological perspective on cemeteries (and life in general). Thanks also go to Jacqueline Hettel, Bill Kretzschmar, Sheila Skemp, Jeremy Smith, and Clive Upton for their feedback and support of this pilot study and for the larger project it represents.

\section{Notes}

${ }^{1}$ Note that, due to individual circumstances, not every informant was asked every question. In addition, informants didn't always respond to every item. Fieldworkers wrote down responses with differing parameters of what to record; for this reason, some responses appear to be less relevant than others. All responses elicited are included in the online databases for each target; it is left to the discretion of the researcher to deem specific responses "irrelevant". Though it is always advisable to err on the side of caution, responses that are clearly irrelevant have been excluded.

2 The very earliest colonial American burials were most likely mass graves (Crissman, 1994) or, at least, multiple interments (Weglian, 2006).

${ }^{3}$ The oldest legible gravestones in America are the 1644 stone of Reverend Ephraim Huitt (Palisado Cemetery in Windsor, CT) and the 1642 marker for Sara Teffl (Occupessatutext Cove in Warwick, RI). 
4 "Dethlefsen," I let pass without comment, but I can't quote Coffin without noting that, for some academics, a future field of study certainly seems pre-ordained.

5 The spread of Enlightenment ideas to America also met with resistance. This reactionary path is exemplified by Rev. Charles Finney, who preached of a world "governed by religious self-control" (as quoted in Farrell, 1980:25). Finney taught that one had to have a conversion experience to be "saved," and it is within this doctrine that we see the beginnings of the evangelical movement in America.

${ }^{6}$ Each motif in this chain of gravestone lunette decorations becomes stylized and simplified before transitioning into the next motif. The time periods in which these motifs are found also overlap. Dethlefsen and Deetz (1967) outline three phases of marker motif: Phase I (1680-1740), Phase II (1740-1760), Phase III (1760-1820) with the death's heads appearing in Phases I and II, cherubs in Phases II and III, and the willow \& urn in Phase III.

${ }^{7}$ Or the urn is simply a symbol of the ashes left behind. The urn could be interpreted as the bodily vessel (some gravestones depict a cracked urn, a "broken" vessel, as it were) or it could be the "eternal vessel" that is assumed to live on after death.

${ }^{8}$ Hilltop burials would have a number of associations, from the idea that from that vantage point, the deceased loved ones were able to look after the living, to the belief that hilltop burials would be less likely to be disturbed, and to the view that a hilltop is closer to God (Crissman, 1994).

${ }^{9}$ Enslaved West Africans in the Caribbean retained a number of African burial practices, such as the use of multiple interments, subfloor burials, burial mounds, and the inclusion of personal possessions in graves. Once slaves were taken to the New World, they were (more or less) forced to adopt Christian beliefs and practices, including those practices associated with Christian burials. With only a few scattered exceptions, African American burial practices underwent a rapid assimilation to prevailing Europeans norms (Jamieson, 1995).

10 Plant and human parted ways eventually, as the Boston Horticulture Society ended up with separate charter from the state, thus separating its garden from Mount Auburn Cemetery.

${ }^{11}$ In this manner, the AACS exercised its own belief in predestination.

12 By "quiet," I take Sargent to mean "flat and unmarked."

13 No, I am not making up these names.

${ }^{14}$ Charles Dickens' Tiny Tim is a perfect example. In A Christmas Carol, the Ghost of Christmas Present presents Ebenezer Scrooge with a scene that contains only Tim's crutch, an image reminiscent of Victorian gravestones for children, which were often topped with carvings of favorite toys or of shoes or empty beds-places and things most closely associated with the deceased (Snyder 1992).

15 Memorial park appears in a brief paragraph on the use of the term inurnment (from the quotation, "Olivet Memorial Park provides every service for Entombments, Inurnments, Interments"). Douglas Chretien surmises that inurnment is "obviously formed by analogy to internment [sic]" and supposes that, "now that cremation is becoming more common, the word may become more established." (1934:317). The next word under discussion (by J. R. Schultz) is camelestrian.

16 This represents the attempt to remove human remains from the food chain, a removal made complete with contemporary embalming practices, caskets that are airtight and waterproof, and the limited use of plants and trees in cemeteries.

17 Oddly, the distribution of God's Acre responses is not reflective of the location of the two greatest concentrations of Moravians in the U.S.: Bethlehem, Pennsylvania, and Winston-Salem, North Carolina.

\section{References}

Burkette, Allison. 2013. Parlor talk: Complexity from a historical perspective. American Speech 87(4). 391-411.

Burkette, Allison. 2015. Language and Material Culture. Amsterdam: John Benjamins.

Cassidy, Frederic C. \& Joan Houston Hall. 1985. Dictionary of American Regional English (DARE), 5 vols. Cambridge, Mass: Belknap Press of Harvard University Press.

Coffin, Margaret M. 1976. Death in early America: The history and folklore of customs and superstitions of early medicine, funerals, and mourning. Nashville, Tennessee: Thomas Nelson Inc.

Chretien, C. Douglas. 1934. Inurnment. American Speech 9(4). 317.

Crissman, James K. 1994. Death and dying in central Appalachia: Changing attitudes and practices. Urbana, IL: University of Illinois Press.

Deetz, James \& Edwin Dethlefsen. 1967. Death's head, cherub, urn and willow. Natural History 76(3). 29-37. Plymouth Colony Archive Project: http:/ / www.histarch.illinois.edu/ plymouth/ (Accessed January 15, 2015).

Dethlefsen, Edwin \& James Deetz. 1966. Death's heads, cherubs, and willow trees: Experimental archaeology in colonial cemeteries. American Antiquity 31(4). 502-510.

Edwards, Jonathan. 1741. Sinners in the hands of an angry God. A sermon preached at Enfield, July 8th, 1741. In Reiner Smolinski (ed.), Electronic Texts in American Studies. Paper 54. http:/ /digitalcommons.unl.edu/etas/54

Epstein, Marilyn Scallan. 2015. Jamestown skeletons identified as colony leaders. Smithsonian Science News July 28. http:/ / smithsonianscience.si.edu/2015/07/jamestown-skeletonsidentified-as-colony-leaders /

Farrell, James J. 1980. Inventing the American way of death. Philadelphia: Temple University Press.

Francaviglia, Richard V. 1971. The Cemetery as an evolving cultural landscape. Annals of the Association of American Geographers 61(3). 501-109.

Francis, Doris. 2003. Cemeteries as cultural landscapes. Mortality 8(2). 222-227.

Geertz, Clifford. 1973. The Interpretation of Cultures. NY: Basic Books.

Green, Meg. 2007. Rest in peace: A history of American cemeteries. New York: People's History. 
Jackson, Charles O. 1977. Death in American life. In C.O. Jackson (ed.), Passing: The vision of death in America. NY: Praeger.

Jamieson, Ross W. 1995. Material culture and social death: African-American burial practices. Historical Archaeology 29(4). 39-58.

Jeane, D. Gregory. 1992. The upland South folk cemetery complex. In Richard Meyer (ed.), Cemeteries and gravemarkers: Voices of American culture. Logan, UT: Utah State Univ. Press.

Kretzschmar, William A., Jr., Virginia McDavid, Theodore Lerud \& Ellen Johnson. 1994. Handbook of the linguistic atlas of the middle and south Atlantic states. Chicago: Univ. of Chicago Press.

Kretzschmar, William A., Jr. 2009. Linguistics of Speech. Cambridge: Cambridge UP.

Kurath, Hans. 1939. Handbook of the linguistic geography of New England. Providence: Brown University for the American Council of Learned Societies. [1973. 2nd edn. New York: AMS Press].
Kurath, Hans. 1939-43. Linguistic atlas of New England, 3 vols in 6 parts. Providence: Brown University for the American Council of Learned Societies.

Kurath, Hans. 1949. A Word geography of the eastern United States. Ann Arbor: University of Michigan Press.

Miller, DeMond Shondell \& Jason David Rivera. 2006. Hallowed ground, place and culture. Space and Culture 9(4). 334-350.

Reed, John R. 1975. Victorian Conventions. Athens, OH: Ohio UP.

Slaughter, Gertrude E. T. 1916. Death doors and asphodel. The North American Review CCIV(733). 909-919.

Snyder, Ellen Marie. 1992. Innocents in a worldly world: Victorian children's gravemarkers. In C.O. Jackson (ed.), Passing: The vision of death in America. NY: Praeger.

Weglian, Emily Jane. 2006. Colonial transformations of death and burial: mortuary analysis in North American colonial contexts. $\mathrm{PhD}$ dissertation, Univ. of Minnesota. 